\title{
Economic Growth of Saudi Arabia Between Present and Future According to 2030 Vision
}

\author{
Hanaa Abdelaty Hasan Esmail ${ }^{1,2}$ \\ ${ }^{1}$ Thebes Academy, Egypt \\ ${ }^{2}$ College of Business Administration, Jazan University, KSA \\ Correspondence: Hanaa Abdelaty Hasan Esmail. E-mail: hanaa_abdelaty001@yahoo.com
}

Received: October 31, 2018

doi:10.5539/ass.v14n12p192
Accepted: November 7, $2018 \quad$ Online Published: November 29, 2018

URL: https://doi.org/10.5539/ass.v14n12p192

\begin{abstract}
Saudi Arabia follows a development strategy depending on many factors generating income, such as increasing non-oil investments, production and manufacturing for exports. Investing contributes mainly to diversify sources of income and generate more jobs where it is expected that the contribution of the private sector will enhance productivity in all sectors. These increased business productivities will increase the percentage annual growth rate to $5.2 \%$ in addition to increasing the added value of the oil sector.

Saudi Arabia implemented a lot of policies to be out of the oil control on their economies and this is taken up in the previous papers of growth factors in Saudi Arabia until 2014. But due to the need of less dependence on oil revenues and the need to diversify sources of income, especially in the period following the drop-in oil prices, it's necessary to create added value to the economy of Saudi Arabia, through an econometric model that illustrates oil alternatives income. This paper is based on the analysis of different growth factors after exclusion of oil revenues using the Weighted Least Square.
\end{abstract}

Keywords: 2030 Vision, WLS, manufacturing, non-oil, value-added, Saudi Women

\section{Introduction}

As we know that the growth and development of any country is determined by its GDP and its reliance on its resources, Saudi Arabia being one of the fastest-developed countries is struggling with a weak economy due to the emergence of the challenges, risks and lower oil prices as well as its budget deficit and increased government spending.

So the Saudi governments announced the 2030 Vision, which aims to diversify income sources and away from relying mainly on oil revenues, especially after falling oil prices and instability. It also enhances its partnership with the private sector and the continued fairness and transparency.

Saudi Arabia has seen development in all fields, but if the oil revenues have been used in a rational manner they would have developed a range of sectors without wasting a lot of resources and made possible to achieve the sustainable development in all countries facilities.

There are many contributions to comprehensive development that can be beneficial such as George (1990), Norgaard (1994) explained the contributions of oil-producing countries that would be helpful for the developing countries. Also, Robinson (2012) explained the need to build effective institutions encourage the development. Similarly, Hasan (1970) interested in the development of Iraq's oil especially after many crises happened.

Saudi Arabia is facing an economic crisis after achieving more surplus of oil, for being one of the largest exporters of oil. These crises have emerged particularly after the end of 2014.

The Saudi government announced a deficit in its budget, which forced to withdraw from the foreign reserves and the issuance of bonds, where the central bank's reserves fell from one billion dollars to reach 732 and then $\$ 623$ million in less than 12 months. Due to increased military spending from the 2016 budget, military spending reached $\$ 213$ billion, or about 25 percent of the total budget.

Recently Saudi Arabia has focused on 2030 vision, which considers the most important entrance comprehensive development. There are so many countries that achieved the growth rates without relying on oil revenues such as Canada and Norway are two of the oil-rich countries that have managed to invest oil revenues for the benefit of 
society plus did not rely upon as a sole source of income.

Not only low oil prices are the main reason for the 2030 Vision, but also there are challenges and set of tensions that affected the continuation of the situation in Saudi Arabia like Yemen war and supporting the rebels in Syria. So Saudi Arabia has taken corrective steps to diversify the different sources of income. And away from dependence on oil revenues and it is considered the manpower in order to the human element is basically out of the crisis, instead of the fact that individuals taking advantage of the wealth of the country that the time to achieve productivity and economic booms. There are many objectives that our study is considering such as access to 2030 vision in general, identify the main sectors that generate income in Saudi Arabia, analyze the factors that affect the economic growth of KSA, and to give valuable suggestions.

\section{Literature Review}

Recently there were so many topics that submit an evidence about the relations between different macroeconomics factors on Saudi Arabia especially after drops in oil sector as analyzed by Esmail (2015) on the impact of Oil Revenue and its relationship with all factors that affect growth in domestic product and also focused on investment opportunity and economic growth in Saudi Arabia which has made the country an increasingly attractive destination of investment for foreign investors. The results show there is a positive relationship between Growth Domestic Product and oil revenue.

Taking into account that Samargandi (2017) Tested the volume of production in KSA and its role in GDP by using a time series data where determined the role of industrial and services sector.

In the case of development in energy field Lshehry and Belloumi (2015) explained that there is an urgent need to conserve energy growth in Saudi Arabia using lot of measures of improving efficiency by encouraging investment and the use of alternative and renewable sources of energy such as solar system, wind energy, which will contribute in changing the climate of the country.

To attract attention to alternative sources of oil Alodadi and Benhin (2015), focused on the non-oil sectors in Saudi Arabia which examines the underlying determinants of economic growth in the future by using these factors - non-oil exports, investment, tourism, capital and human resources rather than relying on oil, and ordering them according to whichever affects a greater proportion to the gross domestic product. This is what we will look to in our study, relying on the vision referred recently.

Recently and also with the need to draw attention to the importance of ports as a source of generate income for many countries, So Esmail (2016) argued for increased attention by Maritime economists to review, analyze, and summarize ports efficiency in Saudi Arabia. The results show that Jazan port should improve plus most of the ports needed to achieve desired development. The study tries to suggest some benefits provided the government is interested to develop and apply them.

Hatem et al. (2016), presented an analytical study of the relationship between economic growth and other factors influencing it. Especially fixed capital formation of economic growth and showed that economic development is achieved when productivity increase, reduction in production costs, employment increase, allowing the production of high -quality products, and competition in the markets. As for the funding and its relationship to economic growth Al Mahish (2016) explained that Funding has an impact in the development of various sectors in Saudi Arabia, also pointed out that the loans granted to the private sector will contribute to fix a lot of problems such as increased production, implement some small projects that helping reduce the unemployment rate, and access to a moderate rate of economic growth.

On the other factor of growth- Saqib et al. (2016) showed the role of Saudi women's contribution to the economic development and that they have an active role in increasing the GDP. The study has proved the existence of a positive relationship between women's contribution to economic development has been measuring economic development through its contribution to the GDP rate.

Consequently, Alodadi and Benhin (2015) classified the main factors for growth in Saudi Arabia focusing on the factors of non-oil sector, also classifying Saudi Arabia economy to categories of oil and other non-oil economies.

The study revealed the effect of oil exports the greatest economic growth, also highlighted the importance of the role of investment in the private sector during the period from 1970-2011. As for the investment in Saudi Arabia which is one of the most important sources of income after oil, therefore Atef Alshehry, (2015) explained that there is a relationship between foreign direct investment and economic growth during the period from 1970-2012 using it in internal growth theory and the results showed that since 2000, there is an improvement in economic growth due to the increase in foreign direct investment. 
An extension of the importance of foreign investment in development also is mentioned by Abdulrahim (2015) in the impact of foreign direct investment to the Kingdom of Saudi Arabia and comparing the developing countries, where the study found there is need to rely on foreign direct investment because of their positive effects on Saudi Arabia development.

To know the relationship between the balance of Payment in Saudi Arabia where Al-Mahish (2017) Tested that the balance of payment has a positive role on gross domestic product. Also it provides evidence about the trade in goods or services with 2030 vision. Samargandi et al. (2014) studied the effect of financial development on GDP by using ARDL, the researchers in this paper found there is a positive effect and there is a clear relationship between financial development and economic growth in non-oil sector if compared with oil sector.

At the level of the Gulf states Raphael Espinoza, (2012), described the Gulf states as one of the highest rates in the gross domestic product (GDP) compared to developed countries. Moreover, Hussein (2009) examined the role of foreign investments in the Gulf countries, especially in the Kingdom of Saudi Arabia to reach the measures necessary to increase foreign direct investment using the correlation matrix to investigate the relationship with GDP. But his results showed a weak correlation.

When considering the policies followed in Saudi Arabia, we find Ghazi and Starr (2010) have analyzed a time series of government spending data and its impact on GDP of non-oil during the period 1996: 2005. The results of the study showed that government spending had a positive impact on long-term growth rates in Saudi Arabia.

There is no doubt that the income of any country is linked closely with health care, so there is a need to provide a suitable budget for the health sector, which contributes indirectly to increase the total income of any country, so Abdulkarim (2014) used Granger Approach to study the relationship between spending on health care in Saudi Arabia and economic growth during the period from 1981-2013.

AbouElseoud (2014) examined the relationship between the number of business transactions over the internet and e-marketing to know the importance of commerce. Due to the positive impact on economic growth using a time series of business transactions during the period (2001-2013), the results of analysis reached that e-commerce will contribute to interest in infrastructure and accelerate development.

Salem (2012) focused on the work of business incubators in Saudi Arabia because of the effects of the significant growth and economic development. Moreover, Alshahrani and Alsadiq (2014) stressed the need of study the relationship between government spending and economic growth by using econometric methods. The results showed that an increase in government spending levels will help communities in long term.

According spend on the services sector in Saudi Arabia, Ageli (2013) showed the model that illustrates the relationship between tourism spending and economic growth. The study found a positive relationship between them.

Regarding the role of financial intermediation in achieving growth in Saudi Arabia, Mahran (2012) tested the relationship between financial intermediation and GDP real during the period from 1968-2010. The study showed the existence of barriers to dominate the financial system in Saudi Arabia.

\section{Discussion}

Saudi Arabia is one of the largest oil exporters in the world, where the sector contributes $45 \%$ of the GDP But after the global drop in global oil prices this had an impact on the Saudi economy so it was necessary to look for growth sources instead of oil.

Recently, and after the decline in oil prices globally, the Kingdom of Saudi Arabia has tended to diversify its sources of income in the field of trade, manufacturing, as well as in services, being one of the world's 20 largest economies in terms of economic stability and its attractive environment for investment. On the commercial level, Saudi Arabia has developed its trade from service trade during the Hajj season to have economic objectives, in addition to give the private sector the opportunity to add more value through the privatization of many different government sectors such as airlines, electricity, telecommunications, port services and some education sectors.

Tourism sector is expected to increase the investment of domestic capital for its development. As for the financial sector, Saudi Arabia has used the latest financial systems and infrastructure applied in the major industrial countries. Otherwise by examining the industrial sector, the production of manufacturing industries in the Kingdom of Saudi Arabia has developed steadily and is heading towards an upward trend based on the development and development of the Saudi manufacturing sector.

This is due to the diversification of the Saudi labor force in various sectors, after the implementation of the saudiaization decision in many areas. The 2030 vision is a clear role aimed at focusing on the Saudi citizen 
before the resident at both men and women without discrimination. The workforce concentrated on Saudi women of professions, both technical and scientific, even in the field of selling and buying. The non-Saudi workforce is increasing in some areas of the construction sector and crafts.

\section{Main Sectors Generating Income Instead of Oil Products}

\subsection{Tourism Sector}

It is one of the most important non-oil sectors, income-generating attracting millions to Mecca and Medina for religious tourism every year. However, there is low tourist revenue because of the Saudis prefer to spend their vacation outside Saudi Arabia.

In addition to the increase in the cost of visas filed by Saudi Arabia, the interest in the tourism sector will increase GDP growth rate.

The most important priorities of the government under the vision of elaborating a plan in order to improve the tourism industry, the most important priority of the government is to create various tourism services in order to attract tourists who come during the pilgrimage season and encourage them to roam around Saudi Arabia .By attracting more tourists, the tourism sector drives economic growth. As it switches the Saudi Arabian system to an open market to foreign investors updating facilities will also attract internal tourists (citizen - residence).

Tourism sector will contribute to the improvement of the economy as it is expected for this important sector that contributes about $11 \%$ after it was contributing to $3 \%$ of GDP. There are many plans that were developed by King Salman to improve the Farasan Island as a tourist destination which contributes to generating returns as substitutes of oil revenues.

The expansion of the infrastructure for some tourism-related Airports and ports will provide travel and career opportunities for men and women and contribute treating the unemployment.

\subsection{Manufacturing Sector}

The manufacturing sector is considered most important non-oil sectors in the Kingdom that can take advantage of the natural and human resources and manufacture internally to meet local and regional demand. There are many private companies that produce to meet the needs and control of the market, which includes citizens and residents. Since 2012 some companies such as Isuzu Automotive began opening a car assembly plant in addition to the manufacturing of some consumer goods in Saudi Arabia.

Besides to the petrochemical sector, which competes with global markets the mining and minerals of Arabia's hand, has major resources such as phosphates, zinc, gold, magnesium limestone and gypsum. But these resources are not exploited the optimal exploitation and an estimated GDP of these resources is less than $3 \%$, so the government must reconsider and attention extracting these resources which will add value added to the Saudi economy.

The Ministry of Commerce and Industry has succeeded over the years to achieve outstanding performance in local industry in all sectors, and achieving results in the various economic indicators compared with the economies of the world where GDP increased from $11.9 \%$ during $1427(\mathrm{H})$ to become $18 \%$ through 1433 . Saudi Arabia has recently increased the number of factories where in 1433 increased in number by $31 \%$ as compared to what it was in 1429, and number of factories reached to 6519 according to the Ministry of Industry and Trade data.

Industrial development in Saudi Arabia has contributed to increasing the employment of various kinds of skilled and unskilled labourers since the industrial sector has provided a large and diverse range of career opportunities in all regions, whether productive jobs, administrative, marketing or other functions.

\subsection{Financing Sectors}

The financial sector plays an important role in economic development and the existence of a diverse and developed financial system that will allow the optimal allocation of resources, which will support investment in Saudi Arabia and maybe extend to around the world. And it includes the Saudi financial system in general, financial and banking institutions and the capital market. These institutions include mainly the Saudi Arabian Monetary Agency and one bank (including the Gulf International Bank branch) and five specialized lending institutions. Moreover, there are 38 enterprise banking, engaged mainly in buying and selling foreign exchange, independent and government institutions, including the interests of the pension and the General Organization for Social Insurance, a large number of agents of foreign insurance companies in addition to the National Company for Cooperative Insurance practiced various types of insurance, such as medical insurance, commercial and various consumer-related insurance services. There are also a few small companies to lease ending with 
ownership and consumer lending. It consists of the capital market of the government securities market and the stock market, corporate debt market, which has recently emerged bonds.

The finance sector that will impact positively in the Vision 2030 is which will serve as the main sector to generate income for economic growth is increasing due to increased lending for small and emerging enterprises as well as medium-sized enterprises.

The existence of an effective financial system is one of the basic requirements for achieving economic growth. Through financial intermediation between savers, investors, lenders and borrowers the financial system encourages savings, investment, and also urges the optimal routing of available investment funds. Moreover, it offers other financial services such as money transfer, guarantees, risk management, financial planning, investment management and advisory services, which have become an increasing need of the society in the current era.

\subsection{Private Sector}

Saudi Arabia's government keeps following the development strategy of the private sector through its support of giant projects in the last five years as a trend to diverse income. This encouraged a lot of businesses to focus on investment in the Kingdom and the expansion of the formation of large national entities. Also, the government provided more support in which the citizens may have difficulty has been the establishment of major companies for the production of a range of industries and services in Saudi Arabia, which increases the chances of achieving more profits.

The strategy of vision 2030 plans to sell parts of the state institutions to the private sector and give that sector a pioneer in the importance of diversifying sources of income and non-oil manufacturing.

From my point of view, the private sector in Saudi Arabia is still suffering as the rest of the Saudi economy from a shortage of local talent and expertise in many professions. This makes the private sector always dependent on foreign labor force and increases in the light of the diversification of income sources and economic sectors plans.

\subsection{Women Manpower}

As Saudi Arabia turned to a computerized economy from once ruled by oil trades especially due to the stability of oil prices, therefore, placed the utmost importance on the transition to a learning-based economy. The key empowering agents of this change will be expanded investment of women power in the private segment and including women in all works according to vision 2030 and the national change program where broadening of the economy and work of Saudi ladies are key needs.

Women in Saudi Arabia are an important element in the growing Saudi economy. More than 6,000 commercial licenses have been issued to women, where they will manage their own businesses. Recently Saudi Arabia introduced a package of reforms to improve the status of women and remove many barriers imposed by Islamic law.

Saudi women have been able to obtain many positions in various sectors such as education, health, Saudi Aramco, the Shoura Council as well as the free business and showed their abilities and excellence. However, because of some customs and traditions that prevent them from taking decisions of leadership especially because of the male dominant society, we find that their role remains marginal, which negatively affects their growth and success, but the rational governments have recently given them the opportunity in some important positions and activate their capabilities and achieve their ambitions and convey a true and honorable image, thus achieving success and excellence and equality with men.

A large number of women in Saudi Arabia have begun to make tremendous progress in entrepreneurship, dealing with huge organizations and male-dominated institutions to carry out one of the good checks of the economy. Many of the women do not wait for access to jobs but contributed themselves to increase national income through its integration in many professions in the field of jewelry, For example, we find a lot of women already working in the field of jewelry and fashion industry.

\section{Methodology}

The methodology of our study is an analytical description, where both were used to illustrate the inferential statistics to get the results based on the assumptions of the study. This study is an extension of my previous research Hanaa Esmail (2015) The period from 2000-2014 indicates the dependence of Saudi Arabia economy on oil only. Therefore, the study assumed assumptions to reach the 2030 vision, and how Saudi Arabia moves away from depending only on the oil as a unique source of income and create new sources of income that will be the first step of economic development. 
According to studying the methodologies used in previous studies, which aimed to identify the economic development situation, especially after the drop-in oil prices even in non-oil countries, Ahmed Alodadi, James Benhin (2015), Hatem et al. (2016). Throw light on the objectives pursued by our current study, the model was developed to measure the impact of the new income-generating variables instead of the impact of oil revenues, which declined after falling prices.

The estimation of the standard model for this study is based on WLS, which requires estimating the time series test of the independent variables until the standard model is estimated.

\begin{tabular}{ll}
\hline Where Y:- dependent Variable ( Eco Growth represented as GDP) & X1: Exports of good or service \%GDP \\
X2: Imports of good or service \%GDP & X3: Agriculture value added \%GDP \\
X4: Industry Value added \%GDP & X5: services value added \%GDP \\
X6: Manufacturing value added \%GDP & X7: high technology as a percentage of manufacturing \\
X8: Medium and high-tech industry (\% manufacturing value added) &
\end{tabular}

\section{Hypothesis}

$\mathrm{H} 0$ : There is no relationship between agriculture value added and economic growth.

H1: There is the relationship between agriculture value added and economic growth.

H02: There are no significant differences between high technology as the percentage of manufacturing and economic growth.

$\mathrm{H} 2$ : There are significant differences between high technology as the percentage of manufacturing and economic growth. (X7, Y)

H03: There is a positive relationship between Imports and economic growth.

H3: There is a strong inverse correlation between Imports and economic growth. (X2, Y)

H04: There is no difference between economic growth and Medium, high tech industry.

H4: There is a difference between economic growth and Medium, high tech industry.

H05: There were no significant differences in the impact of economic growth on manufacturing value added.

H5: There were significant differences in the impact of economic growth on manufacturing value added.

\section{Finding and Analysis}

We can use multiple regression method in the case of a large number of independent variables, and the fact that this analysis is based on linear assumptions between the variables and independence which we can interpret the parameters accurately by using Ordinary Least Square

- Result of data analyzed by using OLS

(1) Table 1 shows the descriptive statistics of the independent variables and the dependent variables entered into the regression equation, showing the mean of each variable with its standard deviation.

Table 1. Descriptive statistics

\begin{tabular}{lccc}
\hline Variables & $\mathrm{N}$ & Mean & Std. Deviation \\
\hline GDP & 14 & 5.19 & 3.478 \\
Exports of good or service \%GDP & 14 & 50.44 & 9.330 \\
Imports of good or service \%GDP & 14 & 29.81 & 7.206 \\
value added agriculture\%GDP & 14 & 2.79 & .690 \\
industry Value added \%GDP & 14 & 57.99 & 6.827 \\
services value added \%GDP & 14 & 41.15 & 7.151 \\
manufacturing value added \%GDP & 14 & 10.48 & 1.091 \\
high technology aspercentage of manufacturing & 13 & .68 & .195 \\
Medium and high-tech industry (\% manufacturing value added) & 13 & 36.39 & 3.562 \\
Valid N (listwise) & 13 & & \\
\hline
\end{tabular}

(2) The results indicate that it is shown by the analysis substantially identical with previous studies, and we can summarize the results of OLS methods, from Table 2 summary table which indicates that the regression model 
used (Enter) methods to whole independent variable in one step $\left(\mathrm{y}, \mathrm{x}_{1}, \mathrm{x}_{2}, \mathrm{x}_{3}, \mathrm{x}_{4}, \mathrm{x}_{5}, \mathrm{x}_{6}, \mathrm{x}_{7}, \mathrm{x}_{8}\right)$. From this table the correlation coefficient indicate that the correlation between the variables is equal to $92 \%$ which shows the strength of the relationship between each other variables, while $\mathrm{R}^{2}$ equal $85 \%$ and adjusted $\mathrm{R}^{2}$ equal $56 \%$ which explicate independent variables. Also, the result of standards deviation shows that regression model by using OLS not significant and we can handle this by using WLS model weighted least squares.

Table 2. Model Summary OLS

\begin{tabular}{ccccc}
\hline Model & $\mathrm{R}$ & $\mathrm{R}$ Square & Adjusted R Square & Std. Error of the Estimate \\
\hline 1 & $.923^{\mathrm{a}}$ & .852 & .557 & 2.308 \\
\hline
\end{tabular}

- $\quad$ Result of data analyzed by using WLS

As a result of the dependent variable data is disproportionate, So the optimal model is weighted least square, to avoid the heterogeneity of the error variance where we found most of independent variable interpret $99 \%$ of the variation in the dependent variable.

Table 3. Model Summary WLS

\begin{tabular}{ccccc}
\hline Model & $\mathrm{R}$ & R Square & Adjusted R Square & Std. Error of the Estimate \\
1 & $1.000^{\mathrm{a}}$ & .999 & .998 & 1.359 \\
\hline
\end{tabular}

Table 4. ANOVA

\begin{tabular}{ccccccc}
\hline & Model & Sum of Squares & df & Mean Square & F & Sig. \\
\multirow{2}{*}{1} & Regression & 12453.070 & 8 & 1556.634 & 842.438 & $.000^{\mathrm{a}}$ \\
& Residual & 7.391 & 4 & 1.848 & & \\
& Total & 12460.461 & 12 & & & \\
\hline
\end{tabular}

- Anova Table shows that correlation rate is equal to $100 \%$. This refers to the strength of the relationship between the variables and each other where adjusted $\mathrm{R}^{2}$ reached to $99 \%$ that model is able to explicate these changes and only $1 \%$ due to other factors. Also we are able to explicate the model from F test equal to (842.4) with significant (0.000), which shows the significance of the model. For regression coefficients and statistical significance of independent variables on the dependent variable, we can summarize the results as follows:

Table 5. Coefficients by WLS

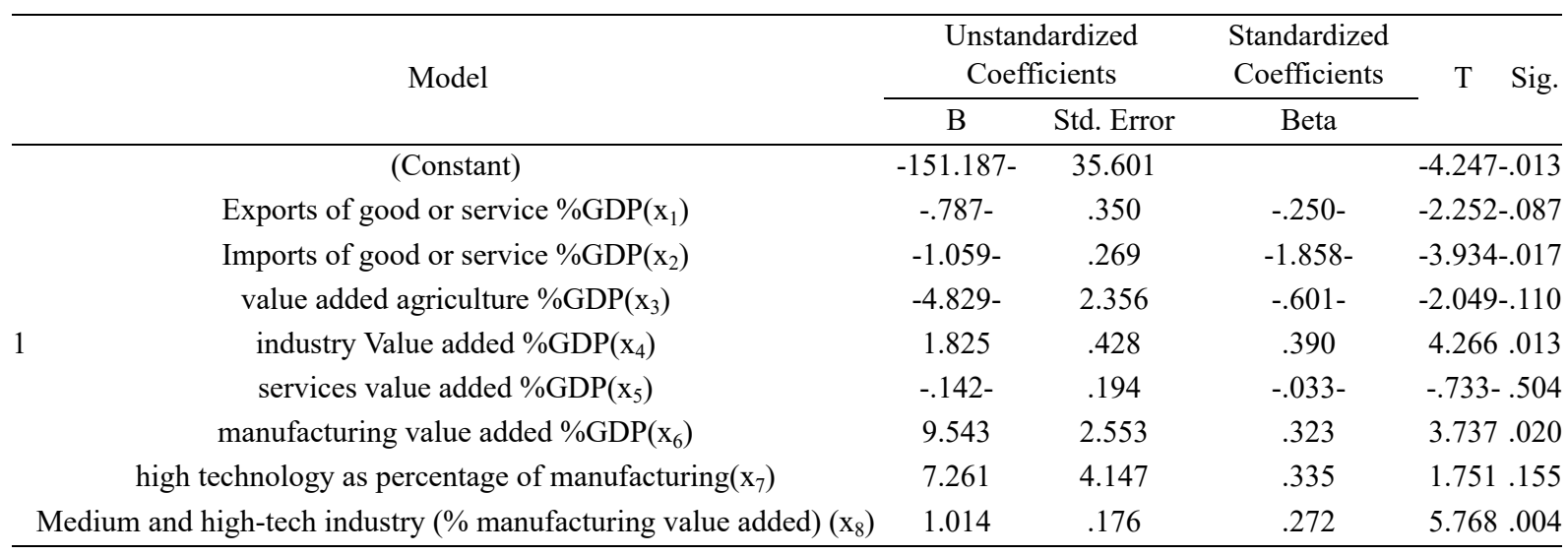

Results of correlation table show that the alternative sources of income play a positive role in the economic growth. This shows that Saudi Arabia has the ability to exit from its reliance on oil revenue and focus on huge export- oriented manufacturing. So we can show table (6) that illustrates the partial correlation between variables and estimate the Regression equation as following:

$\mathrm{Y}=\mathrm{b} 0+\mathrm{b} 1 \times 1+\mathrm{b} 2 \times 2+\mathrm{b} 3 \times 3+\mathrm{b} 4 \times 4+\mathrm{b} 5 \times 5+\mathrm{b} 6 \times 6+\mathrm{b} 7 \times 7+\mathrm{b} 8 \times 8+\mathrm{u}$

$\mathrm{Y}=-151.187-0.487 \times 1-1.059 \times 2-4.829 \times 3+1.825 \times 4+0.142 \times 5+9.543 \times 6+7.261 \times 7+1.014 \times 8+u$

Anova table illustrates that the model is significant to interpret the relationship between variables where is equal to 0.000 , This means that all independent variables have a significant role in verifying some assumptions. 
Table 6. Correlation Matrix

\begin{tabular}{|c|c|c|c|c|c|c|c|c|c|}
\hline & $\mathrm{Y}$ & $\mathrm{X} 1$ & $\mathrm{X} 2$ & X3 & $\mathrm{X} 4$ & $\mathrm{X} 5$ & X6 & $\mathrm{X} 7$ & $\mathrm{X} 8$ \\
\hline \multirow{2}{*}{$\mathrm{Y}$} & .311 & $-.712-^{* *}$ & .414 & .329 & -.280 & $-.362-$ & $-.713-^{* *}$ & .156 & .311 \\
\hline & .279 & .004 & .141 & .250 & .332 & .203 & .006 & .611 & .279 \\
\hline \multirow{2}{*}{$\mathrm{X} 1$} & .311 & 1 & $-.095-$ & $-.104-$ & $.983^{* *}$ & $-.828-^{* *}$ & $-.969-^{* *}$ & -.019 & $.641^{*}$ \\
\hline & .279 & & .746 & .723 & .000 & .000 & .000 & .952 & .018 \\
\hline \multirow{2}{*}{$\mathrm{X} 2$} & $-.712-^{* *}$ & $-.095-$ & 1 & $-.767-^{* *}$ & $-.070-$ & .238 & .190 & $.768^{* *}$ & $-.041-$ \\
\hline & .004 & .746 & & .001 & .813 & .412 & .516 & .002 & .894 \\
\hline \multirow{2}{*}{$\mathrm{X} 3$} & .414 & $-.104-$ & $-.767-^{* *}$ & 1 & $-.206-$ & $-.175-$ & .068 & $-.381-$ & .111 \\
\hline & .141 & .723 & .001 & & .479 & .549 & .817 & .199 & .717 \\
\hline \multirow{2}{*}{ X4 } & .329 & $.983^{* *}$ & $-.070-$ & $-.206-$ & 1 & $-.764-^{* *}$ & $-.966-^{* *}$ & -.059 & .511 \\
\hline & .250 & .000 & .813 & .479 & & .001 & .000 & .847 & .075 \\
\hline \multirow{2}{*}{$\mathrm{X} 5$} & -.280 & $-.828-^{* *}$ & .238 & $-.175-$ & $-.764-^{* *}$ & 1 & $.777^{* *}$ & .012 & $-.455-$ \\
\hline & .332 & .000 & .412 & .549 & .001 & & .001 & .970 & .118 \\
\hline \multirow{2}{*}{ X6 } & $-.362-$ & $-.969-^{* *}$ & .190 & .068 & $-.966-^{* *}$ & $.777^{* *}$ & 1 & .102 & $-.626-^{*}$ \\
\hline & .203 & .000 & .516 & .817 & .000 & .001 & & .740 & .022 \\
\hline \multirow{2}{*}{ X7 } & $-.713-^{* *}$ & -.019 & $.768^{* *}$ & $-.381-$ & -.059 & .012 & .102 & 1 & .090 \\
\hline & .006 & .952 & .002 & .199 & .847 & .970 & .740 & & .771 \\
\hline \multirow{2}{*}{ X8 } & .156 & $.641^{*}$ & $-.041-$ & .111 & .511 & $-.455-$ & $-.626-^{*}$ & .090 & 1 \\
\hline & .611 & .018 & .894 & .717 & .075 & .118 & .022 & .771 & \\
\hline
\end{tabular}

**. Correlation is significant at the 0.01 level (2-tailed).

*. Correlation is significant at the 0.05 level (2-tailed).

Table 7. Summarized results

\begin{tabular}{|c|c|c|}
\hline Item & Hypothesis & Result \\
\hline \multirow{2}{*}{1} & H0: There is no relationship between agriculture value added and economic growth. & Acceptable \\
\hline & $\mathrm{H} 1$ : There is relationship between agriculture value added and economic growth. $\left(\mathrm{X}_{3}, \mathrm{Y}\right)$ & Rejected \\
\hline \multirow{2}{*}{2} & $\begin{array}{l}\text { H02: There is no significant differences between high technology as percentage of manufacturing and } \\
\text { economic growth. }\end{array}$ & Rejected \\
\hline & $\begin{array}{l}\text { H2: There is significant differences between high technology as percentage of manufacturing and } \\
\text { economic growth. }\left(\mathrm{X}_{7}, \mathrm{Y}\right)\end{array}$ & Acceptable \\
\hline \multirow{2}{*}{3} & H03: There is positive relationship between Imports and economic growth. & Rejected \\
\hline & $\mathrm{H} 3$ : There is a strong inverse correlation between Imports and economic growth $\left(\mathrm{x}_{2}, \mathrm{Y}\right)$ & Acceptable \\
\hline \multirow{2}{*}{4} & H04: There is no significant difference between economic growth and Medium, high tech industry. & Rejected \\
\hline & H4: There is difference between economic growth and Medium, high tech industry. & Acceptable \\
\hline \multirow{2}{*}{5} & H05: There is no significant differences in the impact of economic growth on manufacturing value added. & Rejected \\
\hline & H5: There were significant differences in the impact of economic growth on manufacturing value added. & Acceptable \\
\hline
\end{tabular}

Taking in account the value of " $\mathrm{T}$ " and regression equation we find that (constant, $\mathrm{x}_{2}, \mathrm{x}_{4}, \mathrm{x}_{6}, \mathrm{x}_{8}$ ) Contribute significantly to the relationship of economic growth to the sources of income generated in the case of the exclusion of oil revenues, and we can sort them according to the degree of impact on the economic situation and according to the added value of the economy in accordance with vision 2030.

\section{Conclusion}

The industrial sector represents an important component of any economy and it consists of those enterprises, which deal with the exploitation of natural resources. There is no doubt that industrialization is the best way of providing economic stability to the country. It improves the balance of payments by changing the pattern of foreign trade of the country. It helps in increasing the export of manufactured goods and thus earns foreign exchange.

Industrial development has had an important impact on the economic growth of a lot of developing countries. Moreover, the tourism sector is considered the most important sector that will generate more income. Therefore, Saudi government has to define long-term development goals as one of the most important sources of alternative income.

Accordingly, the banking industry is the most profitable business sector in Saudi Arabia as an alternative to oil, which was helped by national and foreign banking transactions together with leading Saudi banks and foreign 
companies to be ahead of their counterparts in the Middle East. Saudi banks have focused on following the events by means of technology and update on an ongoing basis which led to the overall improvement of $100 \%$ in the banking infrastructure.

Last but not least from my point of view one thing is certain, that oil revenues will not support the economy in the coming years, but the diversity of revenue to increase industrial productivity, tourism, banking and investment etc. will have a great impact on the increase in income and will be generated alternative sources of income. For example, focusing on manufacturing oil instead of selling it as the raw material will add to the economy.

\section{Recommendations}

1. Firstly, to take reform measures and realistic policies by the government to review the situation of the country.

2. Increase cooperation between the public and private sectors to absorb unemployment.

3. Reconsider the education systems of the universities and the need to reduce spending on educational missions

4. In light of the low oil prices internationally, Saudi Arabia should increase the construction of oil refineries, producing and exporting petroleum products rather than exporting crude oil.

5. Must to optimize the use of many natural resources such as magnesium, gypsum, zinc, and limestone as alternative resources for oil, which will have added value to the gross domestic product.

6. The need to impose taxes on companies and the citizens on income which will contribute to alleviating the deficit in the budget and which will contribute to economic development and direct tax revenue to serve the citizens.

7. Taking $50 \%$ or more than, as reserves to cover the deficit in the budget rather than fully used and diversify sources of income, either through income taxes or manufacturing.

8. Stop the bonuses allocated to the students in universities and give it to those who deserve all, this will help in reducing the emerging budget deficit.

9. Review of spending in all sectors in the state institutions and even smaller units.

10. Reconsider the appointments, salaries systems and retired workers in comparison to salaries with workers in developed countries

11. Confirm the role of the state in the construction of infrastructure and the development of non-oil productive sectors, plus allocate a percentage of spending to improve infrastructure instead of starting new projects.

12. The allocation of a large percentage of the oil revenues to support productive projects by the private sector.

13. Change investment laws to make it easier to include companies from the junior national investors.

\section{References}

Abou Elseoud, M. S. (2014). Electronic commerce and economic growth in Saudi Arabia. International Journal of Economics, Commerce and Management United Kingdom, 2(5). Retrieved from http://ijecm.co.uk/

Acemoglu, D., \& Robinson, J. (2012). Why Nations Fail, the Origins of Power, Prosperity, and Poverty. Profile Books, London. https://doi.org/10.1355/ae29-2j

Al Mahish, M. (2016). The Impact of Financing on Economic Growth in Saudi Arabia. International journal of Economic and Finance. https://doi.org/10.5539/ijef.v8n8p1

Al-Habees, M. A. (2012). The Relationship Between Unemployment and Economic Growth in Jordan and Some Arab Countries. World Applied Sciences Journal. Retrieved from https://pdfs.semanticscholar.org

Alhowaish, A. K. (2014). Exports, Imports and Economic Growth in Saudi Arabia: An Application of Cointegration and Error-Correction Modeling. Retrieved from http://www.penseejournal.com

Alhowaish, A. K. (2014). Healthcare Spending and Economic Growth in Saudi Arabia: A Granger Causality Approach. International Journal of Scientific \& Engineering Research, 5(1).

Al-Mahish, M. (2017). Does Balance of Payments Constrained Growth Model Hold in Saudi Arabia? Journal of Finance and Economics Research, 2(1), 1-15.

Alodadi, A., \& Benhin, J. (2015). Religious Tourism and Economic Growth in Oil-Rich Countries: Evidence from Saudi Arabia. https://doi.org/10.3727/108354215X14464845877995

Esmail, H. (2015). Factors of Economic growth in KSA an empirical analysis from 2000:2014. International 
Journal of Business and Economic Development, 3(3). Retrieved from http:// www.ijbed.com/

Esmail, H. (2016). Efficiency Assessment of Jazan Port Based on Data Envelopment Analysis. Mediterranean Journal of Social Sciences. Retrieved from http://www.mcser.org/

George, S. (1990). Ill Fares the Land. Penguin Book, London.

Hasan, M. S. (1970). Role of Foreign Trade in the Economic Development of Iraq 1864-1964, a Study in the Growth of a Dependent Economy. In M. A. Cook (Ed.), Studies in Economic History of the Middle East. Oxford University Press, London. Retrieved from http://iraqieconomists.net/en/

Hatem et al. (2016). Determinants of Economic Growth in the Kingdom of Saudi Arabia: An Application of Autoregressive Distributed Lag Model. Applied Economic and Finance.

Hussein, M. A (2009). Impacts of Foreign Direct Investment on Economic Growth in the Gulf Cooperation Council (GCC) Countries. International Review of Business Research Papers, 5(3).

Joharji, G. A., \& Starr, M. A. (2010). Fiscal policy and growth in Saudi Arabia. Retrieved from https://www.american.edu/cas/economics

Lshehry, A. S., \& Belloumi, M. (2015). Sustainable Energy Development in Saudi Arabia. Retrieved from http://www.mdpi.com/journal/sustainability/

Mahran, H. (2012). Financial Intermediation and Economic Growth in Saudi Arabia: An Empirical Analysis 1986-2010. Retrieved from http://www.Scirp.org

Norgaard, R. B. (1994). Development Betrayed, the End of Progress and a Co evolutionary Revisioning of the Future. Rutledge, London and New York. Retrieved from https://www.amazon.com/

Salem, I. M. (2014). The Role of Business Incubators in the Economic Development of Saudi Arabia. International Business \& Economics Research Journal, 13(4). https://doi.org/10.19030/iber.v13i4.8694

Samargandi, N. (2017). Sector value addition, technology and $\mathrm{CO}_{2}$ emissions in Saudi Arabia. Renewable and Sustainable Energy Reviews. https://doi.org/10.1016/j.rser.2017.04.056

Samargandi, N. et al. (2014). Financial development and economic growth in an oil-rich economy: The case of Saudi Arabia. Economic Modelling, 43. https://doi.org/10.1016/j.econmod.2014.07.042

Saqib, N. et al. (2016). Women Empowerment and Economic Growth: Empirical Evidence from Saudi Arabia. Advances in Management \& Applied Economics, 6(5).

Appendix

\begin{tabular}{|c|c|c|c|c|c|c|c|c|c|c|}
\hline Years & $\begin{array}{c}\text { GDP } \\
\mathrm{Y}\end{array}$ & $\begin{array}{l}\text { Exports of good } \\
\text { or } \\
\text { service } \% \text { GDP } \\
\text { X1 }\end{array}$ & $\begin{array}{c}\text { Imports of good } \\
\text { or } \\
\text { service } \% \text { GDP } \\
\text { X2 }\end{array}$ & $\begin{array}{c}\text { Agriculture } \\
\text { value } \\
\text { added \%GDP } \\
\text { X3 }\end{array}$ & $\begin{array}{c}\text { industry Value } \\
\text { added \%GDP } \\
\text { X4 }\end{array}$ & $\begin{array}{c}\text { services value } \\
\text { added \%GDP } \\
\text { X5 }\end{array}$ & $\begin{array}{c}\text { trade in } \\
\text { service } \% \\
\text { GDP }\end{array}$ & $\begin{array}{l}\text { manufacturing } \\
\text { value } \\
\text { added \%GDP } \\
\text { X6 }\end{array}$ & $\begin{array}{l}\text { high technology } \\
\text { as percentage of } \\
\text { manufacturing } \\
\text { X7 }\end{array}$ & $\begin{array}{c}\text { Medium and } \\
\text { high-tech industry } \\
\text { (\% manufacturing } \\
\text { value added) }\end{array}$ \\
\hline 2003 & 11.2 & 46.1 & 14.7 & 4.5 & 54.6 & 40.9 & 12.3 & 10.7 & 0.5 & 35.9 \\
\hline 2004 & 8 & 51 & 15.5 & 3.9 & 57.2 & 38.9 & 12.2 & 10.3 & 0.3 & 34.7 \\
\hline 2005 & 8 & 57.1 & 24.9 & 3.2 & 62.1 & 34.7 & 13.6 & 9.5 & 0.6 & 41.7 \\
\hline 2006 & 5.6 & 59.8 & 30.1 & 2.9 & 62.9 & 34.2 & 16.9 & 9.6 & 0.9 & 41.3 \\
\hline 2007 & 2.8 & 59.9 & 34.9 & 2.8 & 63 & 30.9 & 19.1 & 9.9 & 0.7 & 41.2 \\
\hline 2008 & 6.2 & 62.1 & 34 & 2.3 & 66.8 & 42.1 & 16.3 & 9 & 0.8 & 41.2 \\
\hline 2009 & -2.1 & 47.1 & 37.8 & 2.9 & 55 & 39 & 19.7 & 10.9 & 1.1 & 32.9 \\
\hline 2010 & 5 & 49.7 & 33.1 & 2.6 & 58.4 & 43.2 & 16.6 & 11 & 0.7 & 32.2 \\
\hline 2011 & 10 & 56.2 & 29.6 & 2.2 & 63.7 & 35.2 & 13.3 & 10 & 0.6 & 33.8 \\
\hline 2012 & 5.8 & 54.4 & 29.3 & 2.1 & 62.7 & 38 & 11.5 & 9.8 & 0.6 & 34 \\
\hline 2013 & 2.7 & 51.8 & 30.6 & 2.2 & 59.9 & 40.6 & 11.9 & 9.9 & 0.7 & 34.8 \\
\hline 2014 & 3.7 & 46.9 & 33.8 & 2.2 & 57.2 & 52.1 & 14.9 & 10.8 & 0.6 & 35 \\
\hline 2015 & 4.1 & 33.4 & 38.9 & 2.6 & 45.1 & 52.3 & 15.7 & 12.4 & 0.8 & 34.4 \\
\hline 2016 & 1.7 & 30.7 & 30.2 & 2.7 & 43.3 & 54 & 13.5 & 12.9 & 0 & 0 \\
\hline 2017 & 0 & 0 & 0 & 0 & 0 & 0 & 0 & 0 & 0 & 0 \\
\hline
\end{tabular}

\section{Copyrights}

Copyright for this article is retained by the author(s), with first publication rights granted to the journal.

This is an open-access article distributed under the terms and conditions of the Creative Commons Attribution license (http://creativecommons.org/licenses/by/4.0/). 